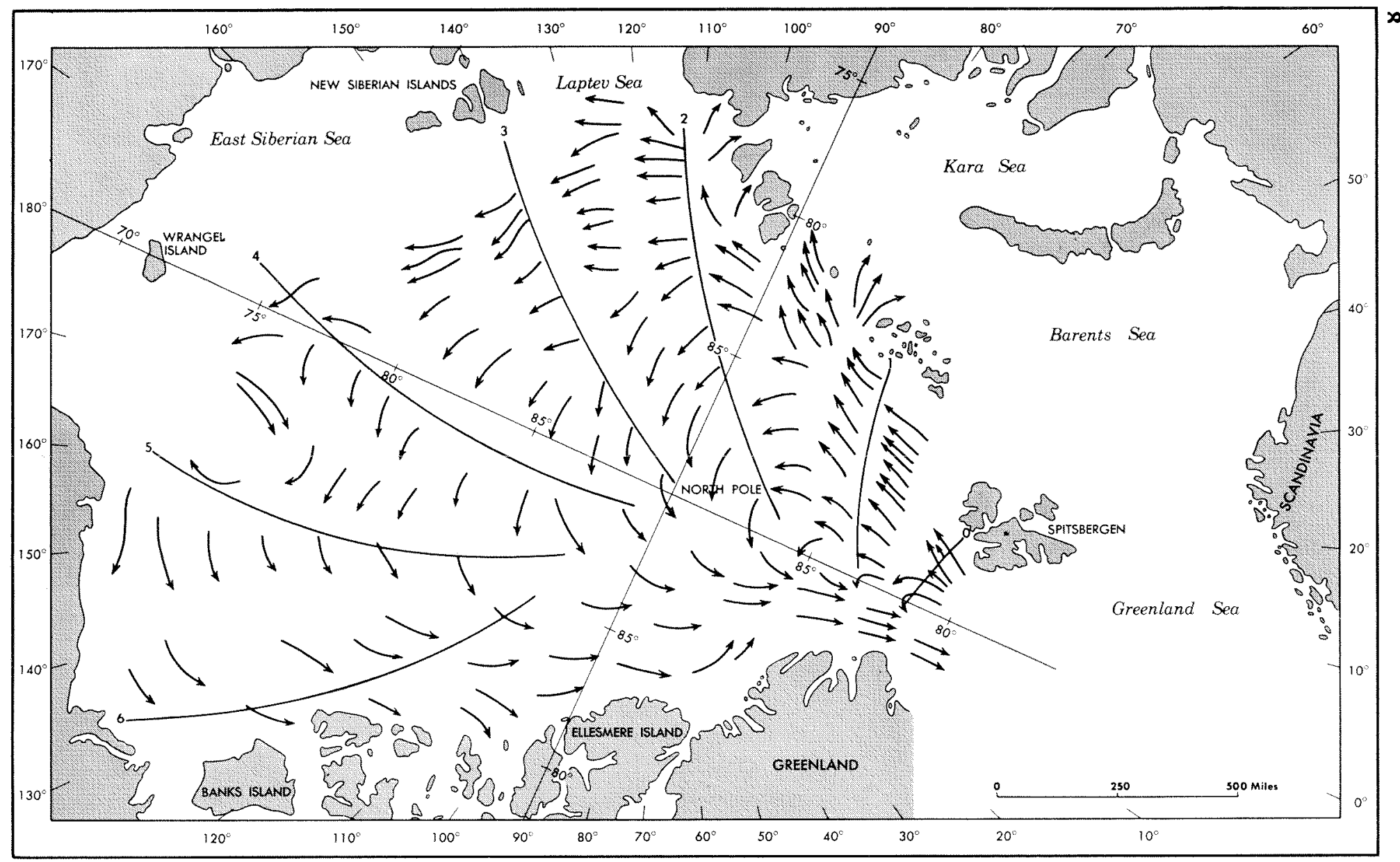

Fig. 1. The circulation of Atlantic water according to Timofeyev 1957. Arrows indicate water movement and numbered lines indicate travel time in years. 


\title{
Papers
}

\section{THE MOVEMENT OF ATLANTIC WATER IN THE ARCTIC OCEAN*}

\author{
L. K. Coachman and C. A. Barnesł
}

W ATER with relatively high temperature $\left(>3^{\circ} \mathrm{C}\right.$.) and salinity (slightly above 35\%o) enters the Arctic Ocean through the strait lying between Spitsbergen and Greenland and then occupies the level between approximately 200 and 900 metres. During the last century it was known (cf. Mohn 1887) that a branch of the North Atlantic current system flowed north through the eastern part of the Norwegian and Greenland seas, but it was Nansen (1902 et seq.) who first observed this water layer in the Arctic Ocean and recognized its connection with water of Atlantic origin. In 1910 (Helland-Hansen and Nansen 1912) and 1912 (Nansen 1915), Nansen studied this water where it enters the Arctic Ocean to the west and northwest of Spitsbergen in more detail and established that: (i) the water flows into the Arctic Basin as a well-defined current, which holds to the continental slope next to Spitsbergen and after passing Spitsbergen turns to the northeast and east, still following the continental slope; and (ii) the temperature of this water varies by $1^{\circ}$ to $2^{\circ} \mathrm{C}$. from season to season and from year to year, whereas its salinity varies little, ranging from 34.95 to $35.10 \%$ o.

Sverdrup (1933) confirmed, in a detailed analysis of the results of the Nautilus expedition, that the main mass of Atlantic water rounds the western coast of Spitsbergen and moves into the Arctic Basin toward the east with a velocity exceeding $10 \mathrm{~cm}$./sec. He also found that there was a more or less continuous flow of water away from the main current to the north and northwest with velocities of the order of $2 \mathrm{~cm} . / \mathrm{sec}$. This water appears to recurve ultimately to the south and flow out of the basin as an underlayer of the East Greenland current.

In the Arctic Basin the Atlantic water initially has a temperature considerably higher than the temperatures of the surface and bottom layers in the basin, and so the course of the main stream, at least for part of its travel, can be inferred from the distribution of maximum temperatures

* Contribution No. 261 from the Department of Oceanography, University of Washington. Support for this work was provided by the Arctic Institute of North America.

$\dagger$ Department of Oceanography, University of Washington. 


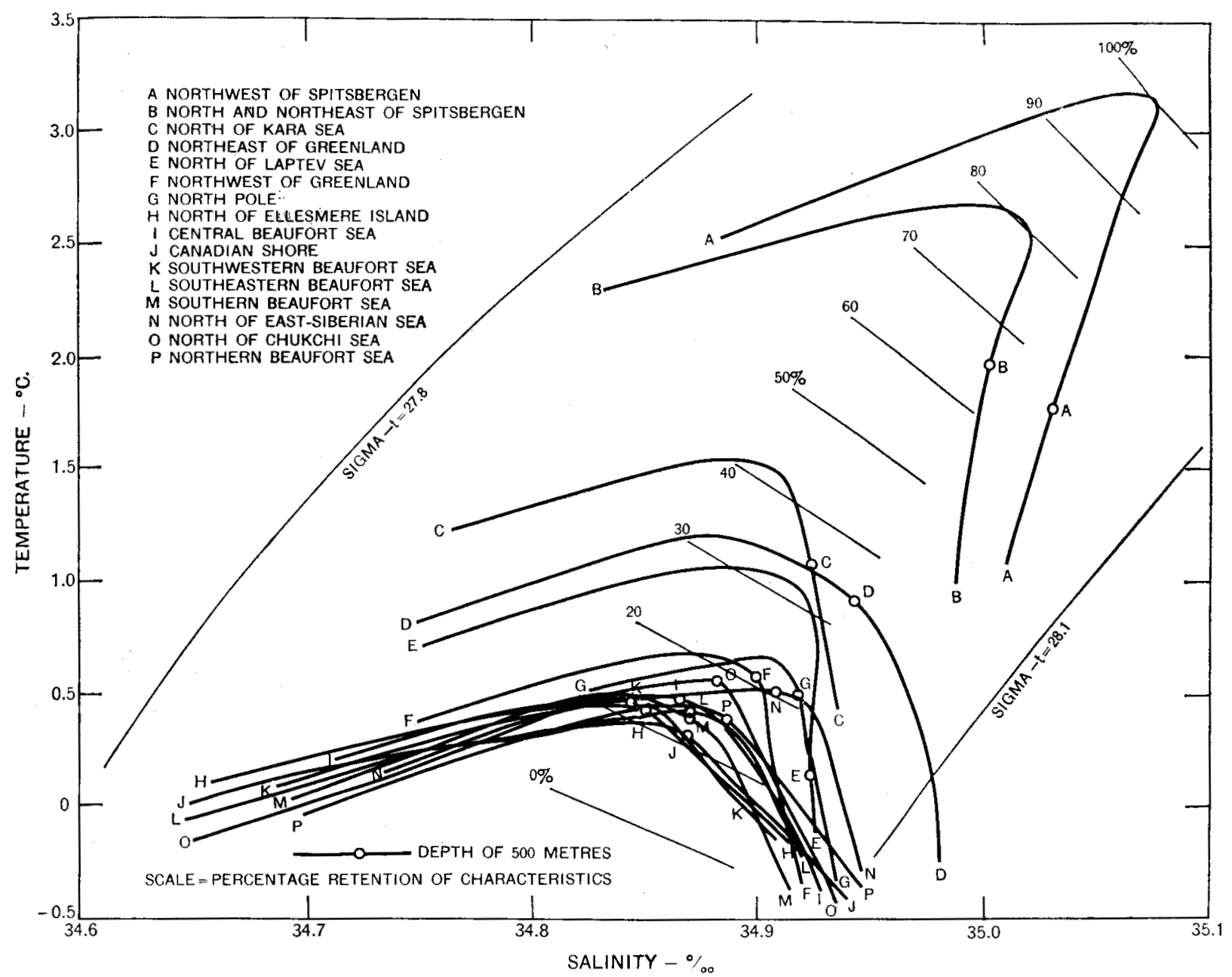

Fig. 2. Temperature-salinity diagram of averages of grouped stations. Groups are indicated in Fig. 3. 
within the layer. The numerous Russian expeditions in the last decade have provided sufficient data for such an analysis and it is now well established that the "core" of the Atlantic inflow, after rounding Spitsbergen, flows east along the continental slope of the Eurasian Basin to the Laptev Sea (Timofeyev 1957, 1960). During this transit a certain amount of the water moves to the north away from the main stream, recurves to the west and southwest and joins the underlayer of the East Greenland current.

In the course of this movement the Atlantic water suffers considerable loss of heat so that on reaching the Laptev Sea its maximum temperature is only about $1^{\circ} \mathrm{C}$. Hence, from this point onward, the temperature is much less useful as a tracer of the Atlantic water movement because over the remainder of the basin its temperature is reduced an additional 0.5 or $0.6^{\circ} \mathrm{C}$., and there can be time and space variations in temperature as large as this due to the seasonal and annual variations in the water entering the basin. However, it must be inferred that the Atlantic water moves in a relatively short period of time into all corners of the basin because: (i) it never loses all its heat to the surface or bottom water layers, its temperature remaining everywhere at least $0.8^{\circ} \mathrm{C}$. higher than that of the other layers; and (ii) its content of dissolved oxygen is everywhere relatively high, greater than $\mathbf{7 0}$ per cent of saturation.

Ultimately, the only satisfactory answer to the question of the movement of Atlantic water will be obtained through numerous direct current measurements. However, because of the difficulties involved, e.g., the low velocities to be measured and the inadequacy of position control of the observer, current observations have not been made routinely and only one set is known to the authors, namely that from drifting station North Pole-2 (Somov 1954-5). Thus, what is known of the Atlantic water movement has been inferred from indirect evidence, and two conflicting schemes of movement have been reported. Fig. 1 shows the scheme that was proposed by Timofeyev (1957) and supported by other Russian workers (cf., e.g., Treshnikov 1959, Sichev 1960, Gordienko and Laktionov 1960). The circulation depicted is a general cyclonic flow of the Atlantic layer around the basin following the continental slope. The flow pattern north of Siberia and Alaska is much broader than it is north of Europe. This pattern is inferred from an analysis of the heat content of the layer, defined as the water between the upper and lower isotherms of $0^{\circ} \mathrm{C}$.

Worthington $(1953,1959)$ has suggested a different circulation pattern in which the Atlantic layer in the Beaufort Sea circulates in the same manner as the surface layer, that is, anti-cyclonically. His scheme, accepted by Sverdrup (1956), is based on examination of the deep (down to $2000 \mathrm{~m}$.) temperature structure.

With assistance from the Arctic Institute of North America we have undertaken to re-evaluate all available oceanographic data from the Arctic Ocean and in the course of this study have examined nearly 300 deep-water stations (for sources see Coachman and Barnes 1961, 1962). To interpret the movement of the Atlántic layer, the most appropriate method appears 
to be the "core-layer method" of Wuist (1935). This method uses the temperature-salinity relationship and thus incorporates the small reduction in salinity of the layer as well as the large reduction in temperature, as both these quantities are maximal in the entering water and less within the basin.

The data available for the analysis cover 60 years, and all seasons of the year are represented. For applying the method, the stations have been grouped by location (see Fig. 3) and the average curve for each group plotted on a temperature-salinity diagram (Fig. 2). The grouping technique was used because: (i) stations from different seasons and years can be included together to smooth out the rather large seasonal variations in temperature, and also any secular variations that may have occurred; and (ii) in general the observations at any station are too widely spaced in depth to define accurately the temperature and salinity of the Atlantic "core"; the averaging of a number of stations gives a more accurate, though average, representation of the vertical distribution for the locality.

The change of temperature and salinity that the Atlantic water experiences during its life in the basin is shown in Fig. 2. The temperature maximum is reduced by about $3.5^{\circ} \mathrm{C}$., whereas the salinity of the water at the temperature maximum is reduced by about $0.2 \%$. Superimposed on the temperature-salinity relationship is an arbitrary scale indicating percentage retention of the original characteristics.

Advection to all points in the basin in the Atlantic layer is required to maintain everywhere a temperature maximum. If the water velocities and vertical and lateral eddy coefficients are more or less the same throughout the basin, the percentage retention of characteristics becomes a quantitative indicator of distance from the source of the advected water from which the path of movement can be inferred. In the Arctic Ocean the Atlantic water enters with a velocity of the order of $10 \mathrm{~cm} . / \mathrm{sec}$, but this is certainly a maximum value for the general flow in the basin, for nowhere else is the Atlantic stream so concentrated as in the vicinity of Spitsbergen. The average velocity along the core near the Eurasian continental slope has been estimated, from seasonal fluctuations of the core water temperature, at about $3 \mathrm{~cm} . / \mathrm{sec}$. (Timofeyev 1958). The current measurements from North Pole-2 gave average velocities for the various periods of measurements between 1 and $5 \mathrm{~cm} . / \mathrm{sec}$. in the area due north of the Chukchi Sea.

The vertical eddy coefficient associated with the decay of the temperature maximum is much less tangible, and hence values for this quantity are much less certain. Sverdrup (1933) found $K_{z}$ to lie between 20 and $50 \mathrm{~cm} .{ }^{2} / \mathrm{sec}$. for the Atlantic stream in the vicinity of Spitsbergen. Data from drifting station North Pole-4 indicated a $\mathrm{K}_{\mathrm{z}}$ of $26 \mathrm{~cm} .{ }^{2} / \mathrm{sec}$. (attributed to Kolesnikov by Sichev 1960). Coachman and Barnes (1961) calculated a value of about $1 \mathrm{~cm} .^{2} / \mathrm{sec}$. for the surface-water layer north of the Chukchi Sea, which had similar temperature gradients and moved with approximately the same velocities as the Atlantic layer. Values have been computed from various ocean areas with small to moderate stability and weak currents in the range 2.8 to $50 \mathrm{~cm} .{ }^{2} / \mathrm{sec}$. (Sverdrup et al. 1942). 


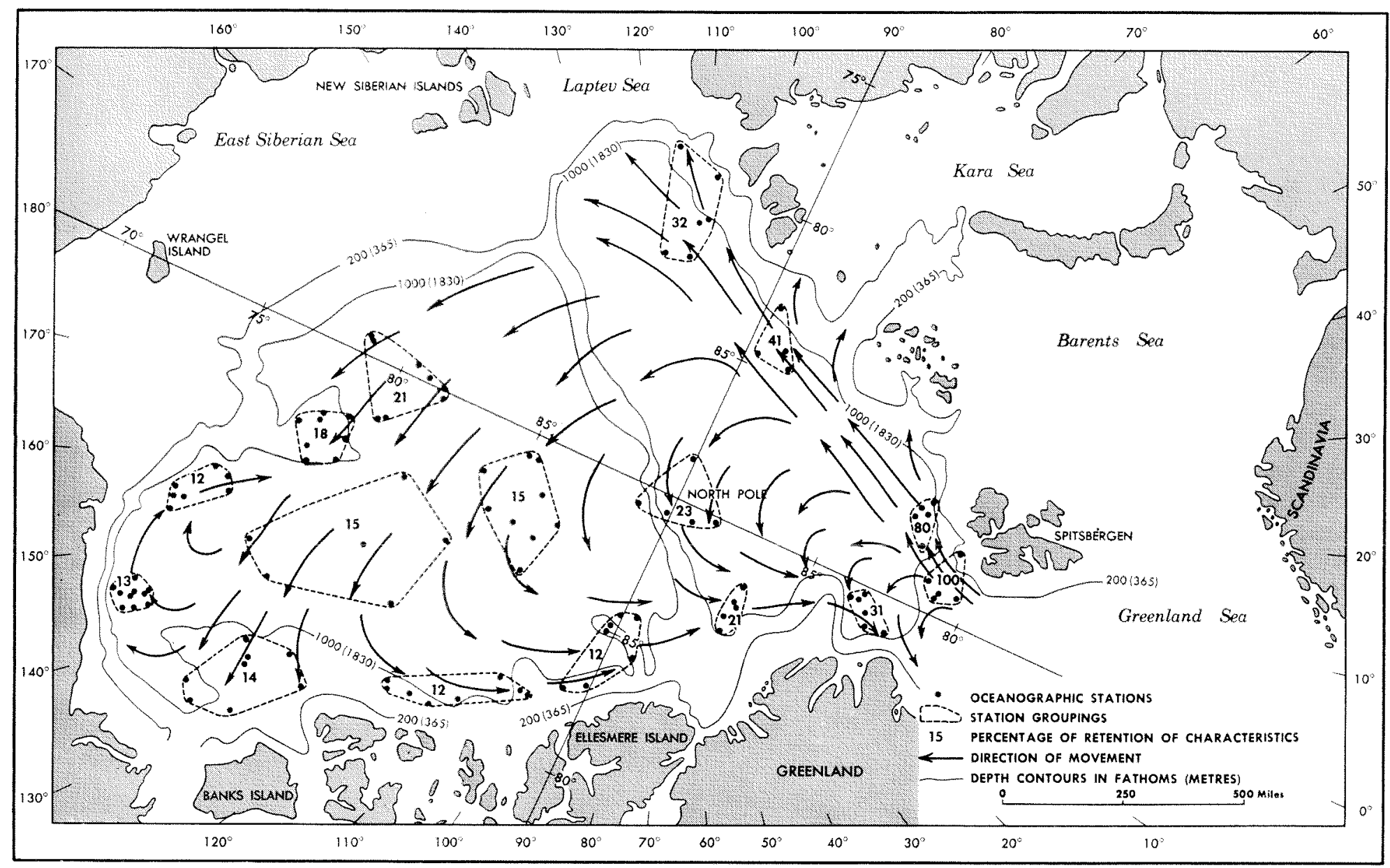

量

Fig. 3. Circulation of Atlantic water inferred from the percentage retention of characteristics. 
Values of the lateral eddy coefficient have not been computed in the Arctic Ocean. Computations of $\mathrm{K}_{\mathrm{y}}$ for other ocean areas have given from $2 \times 10^{6}$ to $4 \times 10^{8} \mathrm{~cm}^{2} / \mathrm{sec}$. (Sverdrup et al. 1942).

The information on velocity and eddy coefficients and the available station data would seem to indicate that there is no area in the Arctic Ocean where the velocity of the Atlantic layer differs significantly from 1 to $10 \mathrm{~cm}$. $/ \mathrm{sec}$., nor where values of $K_{z}$ are much different from 1 to $20 \mathrm{~cm} .{ }^{2} / \mathrm{sec}$. Thus, it appears that the "core-layer method" can be applied with some confidence to the Arctic Ocean for deducing the flow of the Atlantic water.

The percentage retention of characteristics from Fig. 2 is plotted in Fig. 3. The main flow of Atlantic water appears to be along the continental slope of Eurasia from Spitsbergen to north of the Laptev Sea. All along this part of its movement some water feeds off toward the north to the region of the Lomonosov Ridge and then curves toward the southwest to the exit from the basin near East Greenland. Through this "refluxing" movement the Atlantic water fills the Eurasian Basin relatively rapidly, the temperature-salinity characteristic of the layer being everywhere greater than 20 per cent on the arbitrary scale, which is larger than in most of the Canadian Arctic Basin. The water in the Eurasian Basin farthest removed in time from the entrance lies in the area northwest of Greenland.

The Canadian Arctic Basin is filled with water that crosses the Lomonosov Ridge on a broad front from the areas north of the Laptev and Kara seas. This flow apparently parallels the continental slope along the East Siberian and Chukchi seas and then fills the Beaufort Sea, penetrating more or less directly to the area northeast of Alaska and west of Banks Island. This flow appears to turn gradually and spread northward and, last of all, moves eastward along the continental slope of the Canadian Arctic Archipelago and Ellesmere Island, ultimately recrossing the Lomonosov Ridge and joining the outflow from the basin.

The bathymetry north of the Chukchi Sea where a prominent rise protrudes northward into the Canadian Basin apparently prevents a direct penetration of the layer into the region immediately north and west of Point Barrow; this area is filled with Atlantic water that crosses the central Beaufort Sea, recurves to the south and then moves toward the west along the continental slope off Alaska. Such movement is also indicated by a detailed analysis of the data from the Burton Island cruises of 1950 and 1951 (U.S.N.H.O. 1954) and 1960 (unpublished).

The depth of the maximum temperature in the Atlantic layer increases in the course of the movement of this water around the basin. North and northwest of Spitsbergen the maximum temperature is located usually between 150 and $200 \mathrm{~m}$., but by the time the water reaches the Laptev Sea it lies between 200 and $250 \mathrm{~m}$.; north of the Chukchi Sea and in the central Beaufort Sea the depth of the maximum temperature has increased to 400 $500 \mathrm{~m}$. and in the most remote localities, north of Ellesmere Island and northwest of Point Barrow, to rather more than $500 \mathrm{~m}$. The primary reason for the increase in depth of the temperature maximum is probably that the rate 
of loss of heat from the layer is not the same across its upper and lower boundaries. The temperature gradients on the upper side of the layer are everywhere much steeper than on the lower side, and it is not likely that the eddy coefficients are the same on the two sides; in some areas at least a significant velocity shear, which would lead to larger values of $K_{z}$, must be developed on the upper side between the Atlantic water and the surface layer.

The decay of the characteristics of the Atlantic layer, particularly temperature, should be amenable to calculation of eddy coefficients, but over most of the basin the data are not as yet adequate; only along the core paralleling the Eurasian continental slope are the changes great enough for an order of magnitude estimate. Shtokman (1945) considered the temperature distribution along the core to be a balance between horizontal advection and vertical diffusion, but in this area the stream is relatively narrow and the lateral gradients steep, and so a lateral dissipation of heat from the core water may be as important as heat dissipation in the vertical.

Thus the temperature field can be described by $U \frac{\partial \theta}{\partial x}=K_{y} \frac{\partial^{2} \Theta}{\partial y^{2}}+K_{z} \frac{\partial^{2} \theta}{\partial x^{2}}$, where $\mathrm{U}=$ velocity along the core, $\Theta=$ temperature, $\mathrm{x}, \mathrm{y}$, and $\mathrm{z}$ the three co-ordinates, with $\mathrm{x}$ along the core, $\mathrm{y}$ directed laterally, and $\mathrm{z}$ vertically, and $K_{\mathrm{y}}$ and $\mathrm{K}_{\mathrm{z}}=$ constant lateral and vertical eddy coefficients.

With $\mathrm{U}=3 \mathrm{~cm} . / \mathrm{sec}$. and $\mathrm{K}_{\mathrm{z}}=10 \mathrm{~cm} .{ }^{2} / \mathrm{sec}$. (from previous citations), the lateral distribution of temperature taken from a chart of maximum temperature of the Atlantic layer (Timofeyev 1960), and using the station groups of Fig. 2 for temperature distributions in the $\mathrm{x}$ and $\mathrm{z}$ directions, gives an estimate of $K_{y}=8 \times 10^{6} \mathrm{~cm}^{2} / \mathrm{sec}$.

\section{References}

Coachman, L. K., and C. A. Barnes. 1961. The contribution of Bering Sea water to the Arctic Ocean. Arctic 14:145-61.

15:251-77.

Gordienko, P. A., and A. F. Laktionov. 1960. Principal results of the latest oceanographic research in the Arctic Basin. Izv. Ak. Nauk SSSR 5:22-33. (Transl.)

Helland-Hansen, B., and F. Nansen. 1912. The sea west of Spitsbergen. Norske vidensk.ak. Skrifter, I. Mat.-naturv. klasse, No. $12,89 \mathrm{pp}$.

Mohn, H. 1887. The North Ocean, its depth, temperature and circulation. Norske Nordhavs-exped. 1876-1878. Vol. 2, $196 \mathrm{pp}$.

Nansen, F. 1902. Oceanography of the North Polar Basin. Norwegian North Polar Exped. 1893-96. Sci. Results, Vol. 3, No. 9, 427 pp.

1906. Northern waters: Captain Roald Amundsen's oceanographic observations in the arctic seas in 1901. Norske vidensk.-ak. Skrifter, I. Mat.-naturv. klasse, No. 3, 145 pp.

1915. Spitsbergen waters. Norske vidensk.-ak. Skrifter, I. Mat.-naturv.

klasse, No. 2, 132 pp. 
Shtokman, V. B. 1945. Osobennosti rasprostraneniya atlanticheskikh vod v polyarnom basseine. Dokl. Ak. Nauk, Tom 68, No. 1:19-21.

Sichev, K. A. 1960. Teplosoderzhaniye atlanticheskikh vod i raskhodovaniye tepla v arkticheskom basseine. Probl. Arkt. i Antarkt., No. 3:5-16.

Somov, M. M. 1954-5. Edit. Observational data of the scientific research drifting station of 1950-1. Leningrad: Morskoi Transport, Vol. 1, Sec. 2, 3, pp. 48-170, 180-403. (Transl.)

Sverdrup, H. U. 1933. Scientific results of the Nautilus Expedition, 1931. Part 2, Oceanography. Cambridge: M.I.T., Paps. in Phys. Ocean. and Met., Vol. 2, No. 1:16-63

1956. Oceanography of the Arctic. In The Dynamic North, (U.S.N., Chief Nav. Oper. June 1956), Book I, Sec. V, 32 pp.

Sverdrup, H. U., M. W. Johnson, and R. H. Fleming. 1942. The Oceans. New York: Prentice-Hall, 1087 pp.

Timofeyev, V. T. 1957. Atlanticheskiye vodi v arkticheskom basseine. Probl. Arkt. 2:41-51.

Probl. Arkt. 5:27-31.

1958. O "vosraste" altanticheskikh vod v arkticheskom basseine. Izdat., $190 \mathrm{pp}$.

Treshnikov, A. F. 1959. Oceanography of the Arctic Basin. Preprints, Int. Ocean. Congr. Am. Assoc. Adv. Sci., pp. 522-3

U.S. Navy Hydrographic Office. 1954. Oceanographic observations, U.S.S. Burton Island, 1950-1953. H.O. Publ. 618-c, 309 pp.

Worthington, L. V. 1953. Oceanographic results of project Skijump I and Skijump II in the Polar Sea, 1951-1952. Trans. Am. Geophys. Union 34:543-51.

1959. Oceanographic observations. In Scientific studies at Fletcher's Ice Island, T-3, (1952-1955). Geophys. Directorate, U.S.A.F. Camb. Res. Cent., Geophys. Res. Pap. No. 63, Vol. I, pp. 31-5.

Wüst, G. 1935. Die Stratosphäre des Atlantischen Ozeans. Deutsche Atlantische Exped. Meteor, 1925-1927. Wiss. Erg., Bd. VI, 1. Teil, 2. Lief., 288 pp. 